\title{
ORCHIDS' MICROPROPAGATION FOR TO THE SUSTAINABLE MANAGEMENT OF NATIVE SPECIES FROM PARQUE NACIONAL Y ÁREA NATURAL DE MANEJO INTEGRADO COTAPATA (PN-ANMI COTAPATA), LA PAZ-BOLIVIA
}

\author{
Cristina López Roberts ${ }^{1}$, Gabriela Villegas Alvarado, \\ Beatriz Mamani Sánchez, Juan Bermejo Franco, Milenka Aguilar llanos \\ \& Jorge Quezada Portugal
}

Instituto de Biología Molecular y Biotecnología, Campus Universitario, Calle 27 Cota Cota. La Paz-Bolivia

'Author for correspondence: macrissroberts@yahoo.es

KEY WoRDS: orchids, in vitro germination, micropropagation, Yungas Mountain Forest, culture media, conservation

\section{Introduction}

Bolivia is one of eleven countries with the highest biodiversity in earth, due to its variety of ecological belts, ecotones, biogeographic affinities, heterogenic habitats and total species number (Ibish 1996). Concerning to flora, approximately 20,000 angiosperms species have been registered (Beck 1998) and 1,500 of them are included in the Orchidaceae family. The region with the highest orchid diversity corresponds to the Yungas Mountain Forest which covers $4 \%$ of the national extension and has $60 \%$ of the species, being $80 \%$ of them endemic of the zone (Vásquez, 2004). In Bolivia, this group is considered as a priority for conservation since many species have some degree of threat, mainly, due to habitat destruction and selective extraction (Vásquez, 2000). The integration of activities focuses in conservation of these resources within native areas and the development of countryside populations is one of the main challenges to prevent the loss of biodiversity. In this sense in vitro culture techniques provide an alternative for sustainable management of this kind of natural resources. Through these, it's possible to obtain high amounts of plants for trade purposes, diminishing the pressure on the wild populations.

The project "Estudio del potencial de aprovechamiento sostenible de epifitas en el Parque Nacional y Área Natural de Manejo Integrado Cotapata (PN-ANMI Cotapata)" supported by Fondo Flamenco para el Bosque Tropical, has been developing diverse methodologies for the micropropagation of native orchids from the Bolivian Yungas. The plants obtained in vitro will be taken to a communal greenhouse located in "El Chairo" town for their acclimatization. The obtained income will be used to improve economy of the population located in PN-ANMI Cotapata. The presented data constitutes the preliminary results of a 3 years research.

\section{Objectives}

- Micropropagation of native orchid species from PN-ANMI Cotapata

- Evaluation of in vitro germinative response of 10 orchid species

- Comparison of the species' response under two germination treatments (media culture)

\section{Methodology}

Seeds were disinfected in $0.5 \%$ sodium hypochlorite (commercial solution) with two drops of a tensoactive agent during 18 minutes. The media culture used were MS (Murashige \& Skoog 1962) and KC (Knudson C 1946) supplemented with $15 \%$ coconut milk, distributed in culture tubes $(160 \times 10 \mathrm{~mm}$.). This treatment was standarizated after preliminary test based on the protocol described by Villegas (2003). The evaluation of the in vitro germination was made six weeks after the introduction, quantifying the proportion of seeds that have reached any of the different germination stages based on the Pierik's germination criteria (1987) modified by Villegas (2003). Once the germinative process evaluation was finished, the 


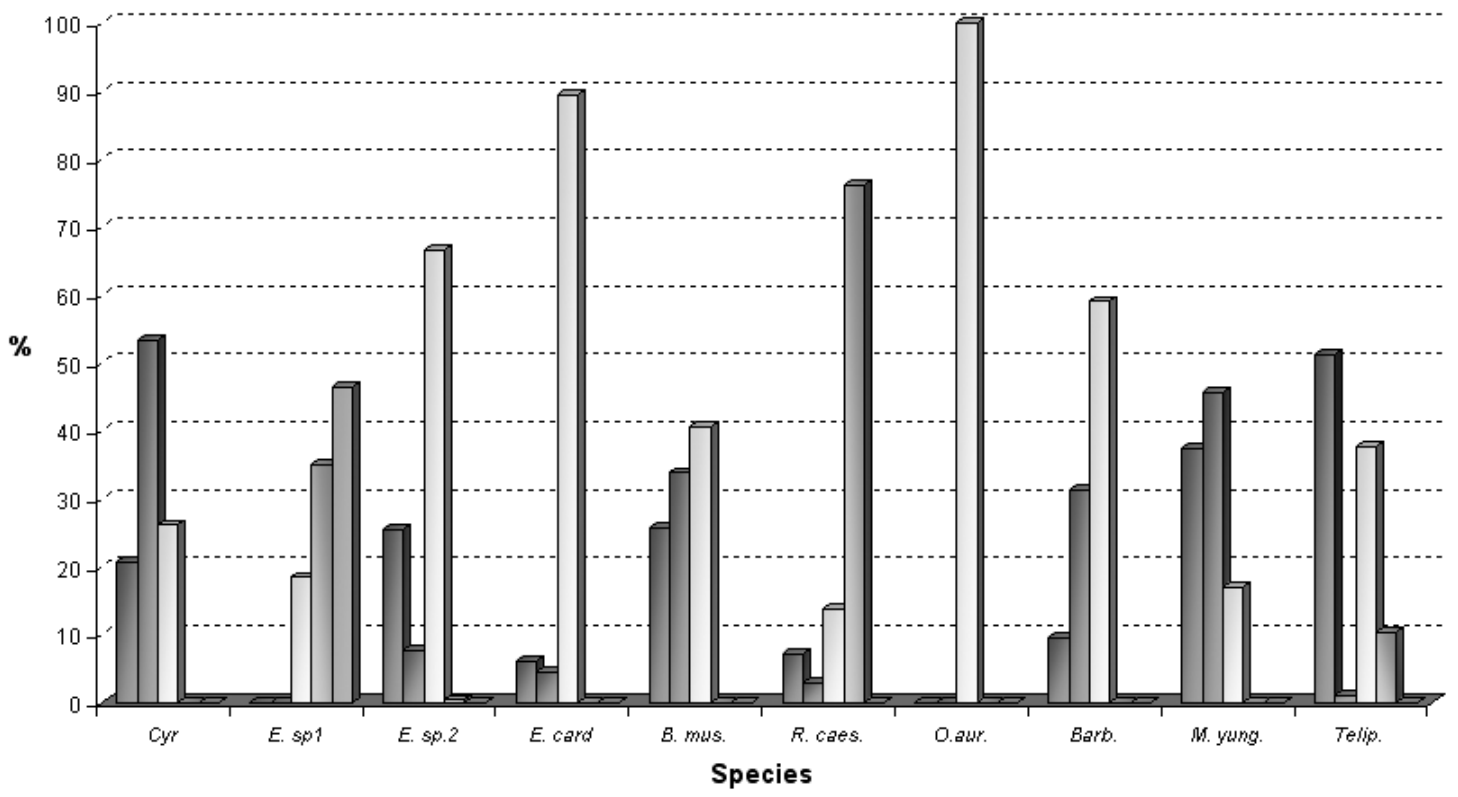

$\square \mathrm{E}-0$ 口E-1 $\square \mathrm{E}-2$ 口-3 $\square \mathrm{E}-4$

FIGURE 1. In vitro germinative process of 10 species of orchids in MS+15\% L.C medium, after six weeks of evaluation. Cyr. Cyrtochilum sp., E. sp1. Epidendrum sp. 1, E. sp2. Epidendrum sp.2, E. card. Epidendrum cardenasii, B. mus. Brachyonidium muscosum, R. case. Rusbyella caespitosa, O.aur. Odontoglossum aureum, Barb. Barbosella sp., M. yung. Masdevallia yungasensis, Telip. Telipogon sp.

in vitro germinated species were transfered to MS medium without growth regulators for its further growth and development.

The studied species were: Bracchionidium muscosum Luer \& Vásquez, Epidendrum cardenasii Hágsater, Masdevallia yungasensis Hashimoto, Odontoglossum aureum (Lindl.) Garay, Rusbyella caespitosa Rolfe, Barbosella sp. Schltr., Cyrtochilum sp. Khunt. Epidendrum L, Epidendrum L and Telipogon sp. Khunt. It is important to mention that for the last five cases, at this moment there is no taxonomic determination at species level, since two of them (Cyrtochilum sp. and Telipogon sp.) could be new species (R. Vásquez, pers. comm. 2006) while in the other cases the bloom time has been expected for their determination.

\section{Results}

After a six weeks evaluation, the most advanced stage of germination in both media culture was E-4 (protocorm with foliar primordial) seen only in Epidendrum (E. sp.1); in this species, the highest rate of germination was registered in $\mathrm{KC}$ medium $(76.1 \%)$ in comparison with MS medium (46.5\%). For the stage E-3 (protocorm), a favorable response was registered in $\mathrm{KC}$ medium too, since five of ten species studied reached it, while in MS medium only three species reached stage E-3. On the other hand, the species Cyrtochilum sp., Bracchionidium muscosum, Odontoglossum aureum and Barbosella sp. only reached stage E-2. In general, the highest rate of species in stage E-2 was observed in $\mathrm{KC}$ medium; however some species showed a more favorable response in MS medium (i.e. Odontoglossum aureum and Barbosella sp.). For stage E-0 (seeds that have not started the germinative process) Masdevallia yungasensis and Telipogon sp. showed highest rate in both media, showing a higher proportion in MS medium (Figures 1 and 2).

The results suggest that $\mathrm{KC}$ medium with $15 \%$ coconut milk is appropriate for the in vitro germination of the species studied in general, since in this medium the most advanced developmental stages (E3 and E-4) were registered (Figure 3). Due to its chemical composition $\mathrm{KC}$ medium has been widely used for the in vitro orchids' germination (Pierik, 


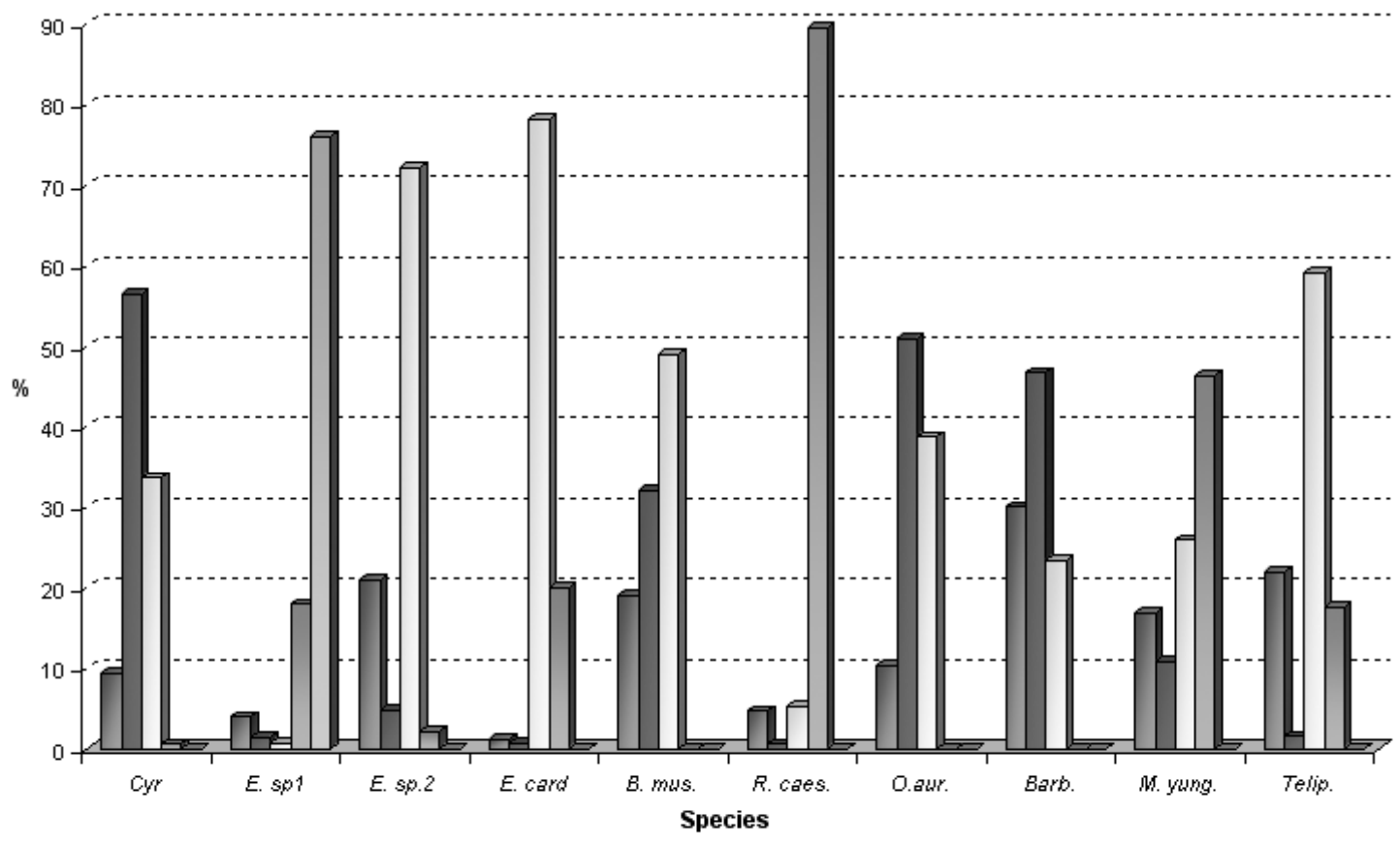

$\square \mathrm{E}-0$ 口E-1 पE-2 पE-3 पE-4

FiguRE 2. In vitro germinative process of 10 species of orchids in $\mathrm{KC}+15 \%$ L.C. medium, after six weeks of evaluation. Cyr. Cyrtochilum sp., E. sp1. Epidendrum sp.1, E. sp2. Epidendrum sp.2, E. card. Epidendrum cardenasii, B. mus. Brachyonidium muscosum, R. case. Rusbyella caespitosa, O.aur. Odontoglossum aureum, Barb. Barbosella sp., M. yung. Masdevallia yungasensis, Telip. Telipogon sp.

1987; Sánchez, 2006), however the present work showed that some species (Odontoglossum aureum and Barbosella sp.) have a more favorable response in MS medium according to the results obtained by Villegas (2003) in Masdevallia chaparensis.

At this time, the project "Estudio del potencial de aprovechamiento sostenible de epifitas en el PNANMI Cotapata" has at least 15 species in germination (without including those reported in this work), 30 in elongation and differentiation, 15 in multiplication and 3 in rooting process. The last ones are ready for acclimatization.

\section{Conclusions}

Usually, the most advanced stages (E-3 and E-4) were registered in $\mathrm{KC}$ medium.

Epidendrum sp.1 was the species with the best in vitro germinative response, since its seeds reached the stage E-4 (protocorms with foliar primordia).

The species Odontoglossum aureum and Barbosella sp. showed a more favorable germinative response in MS medium, in contrast to the other species studied.

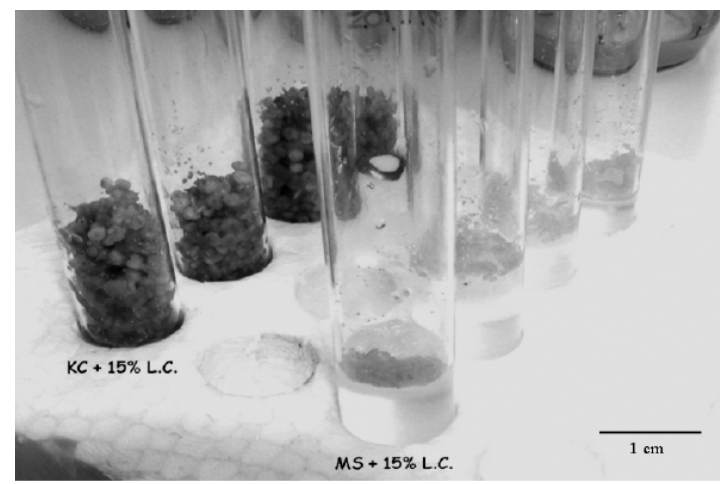

FIGURE 3. Effect of the medium composition on the germination of different orchids' species cultivated in vitro. MS+15\% L.C: Murashige \& Skoog (1962) medium supplemented with $15 \%$ of coconut water. $\mathrm{KC}+15 \%$ L.C.: Knudson C (1947) medium supplemented with $15 \%$ of coconut water. 
ACKNOWLEDGMENTS. We thank to Instituto de Biología Molecular y Biotecnología, Herbario Nacional de Bolivia, Instituto de Ecología, Madidi Project, Luis Pacheco, Iván Jiménez, Fabricio Miranda (botanic researchers), Saúl Sotomayor, Alfredo Sánchez and Lucía Gonzáles. This project was made possible thanks to the financial support of the Flemish Fund for Tropical Forests. This Fund is administered by the Division of Forests and Green Areas (AMINAL, Ministry of the Flemish Community), and supervised by Groenhart vzw. The opinions presented here do not necessarily reflect the position of the Ministry of the Flemish Community or Groenhart vzw.

\section{LITERATURE CITED}

Beck, S.G.1998. Floristic inventory of Bolivia - An indispensable contribution to sustainable development In: Barthlott, W. \& M. Winiger (eds.). Biodiversity - A challenge for development research and policy. Springer - Verlag, Berlin: 243-268.

Ibisch, P. 1996 Neotropische Epiphytendivesität-das Beispiel Bolivien. Wiehl 1996.
Pierik, 1987. In vitro cultura of Higher Plants. Martinus Nijhoff Publishers. Dordrecht (Netherland). 344 pp.

Sánchez, A. 2006. Evaluación de diferentes tratamientos para la germinación in vitro de semillas de Masdevallia exquisita (Pleurothallinidae) del bosque montano de YungasBolivia. Tesis de Grado Lic. Biología. Universidad Mayor de San Andrés. La Paz, Bolivia. 105 pp.

Vásquez, H. R. \& P.L. Ibisch, Ed. 2004. Orquídeas de Bolivia, diversidad y estado de conservación. Vol II. Subtribu Laeliinae, Polystachiinae y Sobraliinae, con actualización y complementación de Pleurothallidinae" 2da edición español. Ed. FAN. Santa Cruz-Bolivia. 649 pp.

Vásquez, H., R. \& P.L. Ibisch, 2000. Orquídeas de Bolivia, diversidad y estado de conservación. Vol I. Subtribu Pleurothallidinae. Ed. FAN. Santa Cruz-Bolivia. 649 pp.

Vásquez, R. 2006. Curso de Biología, ecología y conservación de Orquídeas (entrevista) La Paz, Bolivia.

Villegas, G. 2003. Evaluación del comportamiento in vitro de semillas de Masdevalia chaparensis en respuesta a diferentes tratamientos germinativos. Tesis de Grado Lic. Biología. Universidad Mayor de San Andrés. La Paz, Bolivia 99 pp.

María Cristina López Roberts is a Biologist and Agronomist, specialized in plant tissue culture. She did her thesis work on Micropropagation of Phalaenopsis from flower buds. Since 2004 she is working as a researcher in the Department of Plant Biotechnology, a department from the Institute of Molecular Biology and Biotechnology (Universidad Mayor de San Andrés), focusing on the study of in vitro germination of native orchids from the Bolivian flora. Also, she is studying the phenology and pollinization of Masdevallia's endemic species from the Yungas Mountain Forests.

Gabriela Villegas is a Biologist, she work as a researcher of Plant Biotechnology Department of Molecular Biology and Biotechnology Institute of Universidad Mayor de San Andrés, at La Paz - Bolivia since 2003. She did her thesis about in vitro germination of Masdevallia chaparensis. Her investigation is focused in micropropagation of native and endemic orchids of bolivian Mountain Forest. She is studying the phenology and pollinization of species from Masdevallia genera.

Beatriz Mamani Sánchez is an Agronomist, actually work as a researcher at the Plant Biotechnology Department of Molecular Biology and Biotechnology Institute of Universidad Mayor de San Andrés, at La Paz - Bolivia, working in the project "Estudio del potencial de aprovechamiento sostenible de epifitas en el PN-ANMI Cotapata". Her investigation has been focused in germination and micropropagation of native and endemic orchids of Yungas Mountain forest.

Juan Carlos Bermejo is a biologist, he work as a researcher at the Plant Biotechnology Department of Molecular Biology and Biotechnology Institute of Universidad Mayor de San Andres (La Paz, Bolivia). He has experience in the handling of plant tissue culture procedures applied in massive propagation of different species of orchids.

Milenka Aguilar Llanos is a biologist; she is working as a researcher in the Plant Biotechnology Department of Molecular Biology and Biotechnology Institute of Universidad Mayor de San Andres (La Paz, Bolivia). Actually she is working in training the community people about of orchids sustentable management in PN-ANMI Cotapata.

Jorge Quezada is an Agronomist, born in 1971 at La Paz, Bolivia. He is responsible for Plant Biotechnology Department of Molecular Biology and Biotechnology Institute of Universidad Mayor de San Andrés at La Paz, Bolivia, working as a researcher and professor of Vegetal Biotechnology. He is coordinating of the project "Estudio del potencial de aprovechamiento sostenible de epifitas en el PN-ANMI Cotapata". He has been tutor of degree thesis of Masdevallia genera, endemics from Bolivia. 